DOI: https://doi.org/10.18524/2519-2523.2021.16.245745

УДК 94(477)7.04“1991/2021”М. Дорошенко

\title{
IMAGINARY ICONOGRAPHY OF MYKHAILO DOROSHENKO (1991-2021)
}

\section{Oleksii Doroshenko \\ Olga Kovalevska}

Oleksii Doroshenko

Head's assistant

PROXIMA Ltd

126, Plehanivska str., Kharkiv, 61037,

Ukraine

ORCID ID: https://orcid.org/0000-0002-

8022-691X

E-mail: adoroshenko@proxima.ua

Olga Kovalevska

DSc (History), Leading Researcher

Institute of History of Ukraine, NAS of

Ukraine

4, Hrushevskoho Str., Kyiv, 01001,

Ukraine

ORCID ID: https://orcid.org/0000-00034857-3388

E-mail: o_kovalevska2013@ukr.net

Citation: Doroshenko, O. \& Kovalevska,

O. (2021) Imaginary iconography of

Mykhailo Doroshenko (1991-2021).

Chornomors'ka mynuvshyna, vol. 16,

pp. 104-112.

Submitted: 02.05.2021

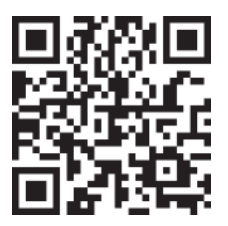

\section{Annotation}

The article is an attempt to systematize and analyse most of the existing images of Hetman Mykhailo Doroshenko created during 1991-2021. A life portrait of the Cossack leader was not found. The probability of the existence of such a portrait is very low due to a number of specific historical reasons of objective and subjective nature, as described in the article. The formation of modern iconography of Mykhailo Doroshenko was due to the growing interest in the biography of this leader of the Zaporozhian Cossacks in the context of the revival of interest in national history during the first years of Ukraine's independence. Further interest in the formation of the iconography of Mykhailo Doroshenko was fostered by the needs of national-patriotic education, museum activities and educational process. Doroshenko's modern iconography is imaginary, it does not reflect the real appearance of the hetman. The vast majority of images of this leader of the Zaporozhian Cossacks are works of the portrait genre, two paintings are made in the battle genre. Doroshenko's fabulous image was also used on philatelic articles and commemorative coins. There have not yet been erected monuments or memorials dedicated to Mykhailo Doroshenko in which the existing imaginary iconographic types of this figure would be used.

Key words: Mykhailo Doroshenko, portraits, iconographic type, iconography

\section{УЯВНА ІКОНОГРАФІЯ МИХАЙЛА ДОРОШЕНКА (1991-2021)}

\section{Олексій Дорошенко \\ Ольга Ковалевська}

Олексій Дорошенко

Заступник директора

ТОВ «Проксіма»

Вул. Плеханівська, 126, Харків, 61037, Україна

ORCID ID: https://orcid.org/0000-

0002-8022-691X

E-mail: adoroshenko@proxima.ua

\section{Анотація}

Стаття є спробою систематизувати та проаналізувати більшість наявних зображень гетьмана Михайла Дорошенка, створених упродовж 19912021 років. Прижиттєвого портрета козацького ватажка не виявлено. Імовірність наявності такого портрета дуже низька через низку конкретних об'єктивних $i$ суб'єктивних причин, описаних $y$ статті. Формування сучасної іконографії Михайла Дорошенка було зумовлене зростанням інтересу до біографії изього очільника запорозького козачтва в 


\section{Ольга Ковалевська}

Доктор історичних наук, провідний науковий співробітник

Інститут історії України НАН

України

Вул. Грушевського, 4, Київ, 01001, Україна

ORCID ID: https://orcid.org/00000003-4857-3388

E-mail: o_kovalevska2013@ukr.net

Цитування: Дорошенко О.,

Ковалевська О. Уявна іконографія Михайла Дорошенка (1991-2021).

Чорноморська минувшина: записки Відділу історії козацтва на півдні України: зб. наук. пр. / за. ред. В.А. Смолія. Одеса: ФОП Бондаренко М.О., 2021. Вип. 16. С. 104-112.

Отримано: 02.05.2021 p. контексті відродження зацікавленості вітчизняною історією впродовж перших років незалежності України. Подальший інтерес до формування іконографії Михайла Дорошенка був викликаний потребами національно-патріотичного виховання, музейної діяльності й навчального прочесу. Сучасна іконографія Дорошенка є уявною, реальної зовніності гетьмана вона не відтворює. Більшість зображень иього очільника запорозьких козаків - ие твори портретного жанру, два полотна виконано в батальному жанрі. Уявний образ Дороченка також використано на філателістичній продукиії та пам'ятних монетах. Пам'ятників або пам'ятних знаків, присвячених Михайлові Дорошенку, в яких було б використано наявні уявні іконографічні типи иієі постаті, поки не встановлено.

Ключові слова: Михайло Дорошенко, портрети, іконографічний тип, іконографія.

Постать гетьмана Михайла Дорошенка $є$ мало висвітленою у сучасній історіографії. 3 часу смерті в

1628 році й досі йому було присвячено лише кілька наукових розвідок і статей. Першою 3 них була розвідка Катерини Мельник “Сведения о походе в Крым Михаила Дорошенко”, опублікована 1896 р. на сторінках часопису "Киевская старина" [18, с. 274-286]. У 1913 р. Михайло Грушевський опублікував невелику статтю "Михайло Дорошенко" [6, с. 252]. Третьою за хронологією була стаття Дмитра Дорошенка, відомого історика, який походив із козацько-старшинського роду Дорошенків, - "Повстання Жмайла і козацькі походи в Крим”, у 1944 р. оприлюднена на шпальтах газети "Український доброволець" [9]. Основою для цієї праці став матеріал першого тому "Нарису історії України” Дмитра Дорошенка. У цій статті було наведено всі відомості щодо дослідження постаті Михайла Дорошенка, відомі на середину XX ст., однак надалі інтерес до цього персонажа так і не призвів до появи грунтовної наукової монографії, як, наприклад, сталося з постаттю Петра Дорошенка [8].

На початку 1990-х pp. на хвилі відродження інтересу українців до власної історії 3'явилася колективна праця українських істориків “Історія України в особах IXXVIII століття", де в розділі, присвяченому Петрові Дорошенку, була інформація й про Михайла [21, с. 318-326]. Пізніше цей текст перевидали в популярному виданні "Гетьмани України", автором якого був Володимир Замлинський [11, с. 172-174, 176-180].

У 1994 р. вийшла друком розвідка Юрія Мицика “Михайло Дорошенко” [20, с. 156-170], яка досі залишається однією з найдетальніших біографій козацького ватажка. У ній було визначено час першої документальної згадки про гетьмана, який у 1618 p. разом із Петром Конашевичем-Сагайдачним брав участь у московській військовій кампанії польського королевича Владислава IV, про захоплення козаками Дорошенка та передачу королевичеві трофеїв, про участь у Хотинській війні 1621 р., про кількаразове перебування на гетьманській посаді (1623, 1624, 1625-1628), про ризиковане рішення втрутитися в боротьбу за престол у Кримському ханстві, яке коштувало йому життя.

У 2009 р. в розділі “Гетман, погибший за хана” у монографії Олекси Гайворонського “Повелители двух материков" з'явилася цікава інформація про стосунки Михайла Дорошенка 3 кримським ханом Мехмедом III Гіреєм (Гераєм) та калгою-султаном Шахін Гіреєм (Гераєм) [4, с. 117-124]. Пізніше на основі тексту цього розділу автор підготував доповідь для науковопрактичної конференції “Історичні уроки доби "Руїни”: Петро Дорошенко - збирач розколотої єдності в пошуках союзника", що відбулася 14 жовтня 2019 р. У збірнику матеріалів конференції стаття Олекси Гайворонського називалася “Гетьман, що загинув за хана": огляд 
подій кримського походу Михайла Дорошенка 1628 року” й містила чимало цікавої інформації, зокрема про особливості військового походу козаків 1628 р. на Крим, про козацько-татарський союз, про загибель Михайла Дорошенка та Оліфера Голуба, а також про місце ймовірного поховання гетьмана та спроби встановити пам'ятник чи пам'ятний знак на місці його загибелі [5, с. 7-39].

Черговий популярний нарис про гетьмана Михайла Дорошенка було опубліковано в 2011 році в науково-популярному виданні "Усі гетьмани України", автором якого був Денис Журавльов [10, с. 117-185].

У 2015 р. основні факти біографії Михайла Дорошенка було висвітлено в статті, присвяченій ролі роду Дорошенків у громадсько-політичному та культурному житті України [1, с. 39-56]. У цій праці гетьмана згадано як засновника роду, представникам якого, власне, й було присвячено статтю. Однак біографічні відомості, які переповідали автори, були повністю запозичені 3 попередніх публікацій і не становили для провідних козакознавців наукового інтересу.

Натомість у наступні роки з'явилося кілька цікавих публікацій, у яких військовополітичну діяльність Михайла Дорошенка розглядали в контексті козацько-татарських відносин першої половини XVII ст. [2, с. 85, 91, 92, 94, 131; 3, с. 95, 96; 7, с. 256 - 260, 263, $264,269,270,273,274,305 ; 22$, с. $35-36 ; 23$, с. 82,84$]$, що заслуговувало на увагу і науковців, $\mathrm{i}$ зацікавленої аудиторії.

Попри наявність певної кількості наукових розвідок, присвячених Дорошенкові, серед них немає повноцінного біографічного дослідження, що зумовлено низкою об'єктивних $\mathrm{i}$ суб'єктивних причин. Брак джерел не дає сучасним історикам змоги однозначно відповісти на елементарні питання, як-от місце народження й вік або походження Михайла Дорошенка. Автори публікацій розходяться в оцінках його дій як політичного діяча, воєначальника, його ролі в розв'язанні складних релігійних питань, які були тоді рушійною силою багатьох подій. Відтак постать цього ватажка - родоначальника козацько-старшинського роду Дорошенків залишається маловідомою широкому загалу українців. Зокрема цей факт позначився й на тому, як образ гетьмана Михайла Дорошенка було відтворено в образотворчому мистецтві. Остатє стало метою даної публікації.

Як відомо, до нашого часу дійшло лише кілька зображень козацьких ватажків XVI ст., зокрема Івана Підкови та Гаврила Голубка. Перший очільник запорозького козацтва помер у 1578 р., другий - у 1588 р., а їхні “портрети” було намальовано в проміжку між 1630 і 1640 рр. Отже, вони не були автентичними, а відтак навряд чи правдиво передають нам їхній зовнішній вигляд.

Iз зображень діячів першої половини XVII ст. до нашого часу дійшла лише гравюра, яка зображала Петра Конашевича-Сагайдачного, виконана в 1622 році одразу після смерті гетьмана. Вірогідно, вона містила окремі портретні риси очільника запорожців, однак була надто схематичною й не давала змоги уявити його психологічний портрет. Натомість це не завадило художникам пізнішого часу використовувати цю гравюру для створення уявноісторичних портретів Петра Конашевича-Сагайдачного.

Подальший період козацько-селянських повстань першої третини XVII ст. вивів на історичну арену чимало козацьких ватажків, однак зафіксувати для нас їхній зовнішній вигляд не було кому й на чому. До того ж портрети тоді побутували лише в певних середовищах i виконували вузько специфічні функції, тож будь-хто не міг собі його дозволити.

Національно-визвольна війна 1648-1657 pp., у ході якої було сформульовано завдання боротьби за державну суб'єктність, сприяла зростанню інтересу й до тогочасних військополітичних подій, i до історичних постатей, які були їхніми учасниками. Інформацію про ті часи відбито в багатьох писемних і зображувальних джерелах - і вітчизняних, й іноземних. У 1651 p. було написано перший повноцінний портрет очільника Війська Запорозького - Богдана Зиновія Хмельницького. 3 часом кількість гравійованих і написаних портретів очільників Гетьманщини та представників козацької старшини почала зростати, однак їх імовірна кількість не відповідала тогочасній кількості козацького стану (причини цього явища були не в політичній, а в економічній 
та культурній площинах), а нині - не задовільняє потреби сучасних дослідників у зображальних джерелах, що наочно відтворювали ту давно минулу добу.

У цьому контексті логічно виникає питання: чи існував прижиттєвий портрет або хоч якесь зображення Михайла Дорошенка? Ні. Жодного прижиттєвого портрета ніколи не існувало з об'єктивних причин. По-перше, тоді не існувало економічних підстав, які традиційно сприяли розвитку мистецтва в країнах Європи. По-друге, Михайло Дорошенко належав до тієї верстви тогочасного населення Речі Посполитої, яка не мала відповідних статків, що давали б змогу оплатити написання портрета. По-третє, на початку XVII ст. портретний жанр міг розвиватися лише у великих містах або при значних мистецьких осередках, як-от при монастирях, однак не на небезпечному річпосполитсько-османокримськоханському прикордонні. По-четверте, портрети тоді тільки починали виконувати репрезентаційну або декораційну функції, до того ж лише в магнатських резиденціях. Нарешті, гетьман за час свого короткого життя не встиг уславитися як меценат чи покровитель церкви, а відтак не міг сподіватися навіть на створення ктиторського портрета. Отже, усі наявні нині зображення цього гетьмана $є$ творчим вимислом і фантазією митців пізніших часів.

Відомі сучасні так звані портрети гетьмана Михайла Дорошенка з'явилися вже після 1991 р. Їх мало, використовували їх лише поціновувачі історії козацької доби. Їх створювали для музейних потреб чи для ілюстрування підручників і популярної літератури.

Нижче розглянемо основні живописні й графічні портрети Михайла Дорошенка, картини історичного змісту за його участі та образи, створені в пластиці, що стало джерельною базою публікацї.

Насамперед слід згадати зображення, виконане на початку 1990-х pp., яке досі використовують як загальноприйняте, хоча й помилкове з погляду іконографії. Йдеться про плакат із зображенням Михайла Дорошенка, надрукований поліграфкомбінатом “Україна". До друку весь набір із 16 плакатів підписали 1 липня 1991 р. Автором портрета Михайла Дорошенка був Олександр Кот (див. ілюстрований додаток: № 1), а однією з трьох авторівупорядників набору плакатів - Галина Ярова, майбутня директорка Музею гетьманства, яка тоді ще працювала в Державному історичному музеї УРСР (після відновлення державної незалежності України й згідно із Постановою Кабінету Міністрів України від 15 жовтня 1991 р. на базі Державного історичного музею УРСР було створено Національний музей історії України). Тоді для друку відібрали портрети козацьких ватажків, які, на думку Галини Ярової, були найбільш видатними постатями в історії ранньомодерної козацької держави. Оскільки автентичного портрета Михайла Дорошенка не існувало, було прийнято рішення створити його уявний портрет. За основу цього зображення художнику надали гравійований образ Юрія Хмельницького, створений Джованні Баттісто Боначіною в 1670 p. У ході роботи над образом гетьмана Олександр Кот надав йому деяких власних портретних рис. Картуш до портрета виконав Микола Мотузка. Відтоді саме цей образ став одним із найпоширеніших і найбільш затребуваних зображень Михайла Дорошенка. Оригінальні акварелі до цього проєкту було передано до видавництва “Україна", де вони мають зберігатися в його архіві.

Пізніше, у травні 1994 р., в уже створеному тоді Музеї гетьманства відкрилася персональна виставка картин художника Олександра Кота, на якій також був присутній Іван Салій, що до 1993 р. очолював Київську міську держану адміністрацію та за ініціативи якого й було створено Музей гетьманства. Серед інших творів митця був виставлений й згаданий портрет козацького ватажка.

Художник Валерій Войтович, який у 1991 р. також створив графічний портрет «козацького гетьмана Михайла Дорошенка» (див. ілюстрований додаток: № 2) пішов іншим шляхом. Його образ виявився цілком уявним, навіяним автору тією літературою, з якою він устиг ознайомитися. Також вона обумовила й історичні помилки, яких припустився художник. Зокрема Валерій Войтович зобразив відрубану голову гетьмана, насаджену на спис, і зазначив в одному 3 підписів, які супроводжували твір, що Михайло Дорошенко загинув під Кафою. Проте нині історики впевнено стверджують, що гетьман загинув під Бахчисараєм на річці 
Альмі 31 травня 1628 р. й до Кафи не дійшов. Де знаходиться могила гетьмана - невідомо [20, c. $163 ; 5$, c. $27-28]$.

Водночас із творчими спробами Олександра Кота та Валерія Войтовича створити хоч якесь зображення Михайла Дорошенка, свій варіант портрета, у властивій лише йому манері виконав Данило Нарбут. Художник тоді працював над низкою портретів діячів козацької доби. Зображення Михайла Дорошенка з'явилося в 1991 р. у серії “Гетьмани України” й нині перебуває в колекції Національного історико-культурного заповідника "Чигирин”. Репрезентуючи глядачам своє бачення образу гетьмана, Данило Нарбут супроводив його портрет кількома картушами, в одному з яких було зображено герб Війська Запорозького козак із мушкетом, у другому - герб Дорошенків, але пізнішого часу, у третьому - герб Чигирина, наданий місту разом із магдебурзьким правом ще в 1592 р. (при зображенні історичного герба Чигирина Данило Нарбут припустився помилки: замість зображення коричневих стріл на білому (срібному) тлі, він зобразив білі стріли на синьому тлі), а в четвертому - текстову інформацію: “Михайло Дорошенко / Гетьман Війська Запорозького Низового / Вбитий під Бахчисараєм” (див. ілюстрований додаток: № 3). Хоча образ Михайла Дорошенка загалом був уявним, художник припустився однієї суттєвої історичної помилки: змалював гетьмана в шапці з павичевим пір'ям, чого тоді ще не могло бути. Доводити історичність чи неісторичність решти елементів одягу чи зброї не є предметом цієї статті, до того ж у цьому немає сенсу, бо портрет було написано не в історично-реалістичній манері, а в театрально-сценографічній.

Наступний доволі оригінальний портрет тушшю й пером у власній, цілком упізнаваній манері виконав у 1994 р. Сергій Якутович. Михайла Дорошенка він намалював із булавою в правиці та шаблею в лівиці, як справжнього козака-відчайдуха, завжди готового до бою. Портрет належав до серії зображень козацьких ватажків, виконаних майстром для календаря (див. ілюстрований додаток № 4).

Одночасно зі зростанням упродовж 1990-х рр. інтересу українського суспільства до різних постатей козацької доби, збільшувалася також кількість різноманітної філателістичної продукції, у якій тоді часто використовували образи козаків, гетьманів і кошових отаманів. Так сталося і з образом Михайла Дорошенка. Хоч як не дивно це виглядає, але саме образ, створений у 1991 р. Олександром Котом, а також більш примітивізований автентичний образ Юрія Хмельницького у виконанні Джованні Баттісто Боначіни, стали найбільш затребуваними під час створення поштових конвертів, марок і віньєток у серіях "Гетьмани України". Саме тому дуже подібними між собою виявилися поштові конверти з образом Михайла Дорошенка, погашені відповідно у 1992 р. (див. № 12), 1993 р. (див. № 13), 1995 р. (див. № 14), поштова картка 1995 р. (див. № 15), приватні наддруки на маркових блоках радянських часів (див. № 18, 19), поштова марка 1995 р. (див. № 20).

Після першого сплеску зацікавлення козацькою тематикою та намагання швидко повернути у громадське середовище, інформаційний простір, дидактичну літературу та візуальний простір імена й образи багатьох постатей зі славного минулого українців, на початку 2000-х рр. інтерес до них частково вщух. Зокрема це стосувалося й постаті Михайла Дорошенка. 3 одного боку, історикам уже в середині 1990-х рр. стало зрозуміло, що нових джерельних свідчень про його життя та діяльність виявити поки що не вдається, а отже, треба докласти зусиль, щоб накопичити новий історичний матеріал для нових праць. Відтак ця постать на певний час стала менш привабливою й для митців. 3 іншого боку - iз плином часу стало більше простору й для переосмислення діянь цієї людини, і для створення нових образів козацького ватажка. Саме так з'явилися абсолютно несхожі між собою мистецькі інтерпретації образу Михайла Дорошенка, створені Феодосієм Гуменюком у 2006 р. (див. № 5) на основі відомих зображень гайдамаків; Семеном Панпушиним у 2007 р. (див. № 6), що став черговою інтерпретацію портрета Юрія Хмельницького, виконаного італійським гравером 1670 року; Олексієм Томіним у 2013 р. (див. № 7), що став повною фантазією автора; українським митцем, який працює під псевдонімом “Cossack”, у 2015 р. (див. № 8). Не обійшлося й без прикрих повторів і відвертих помилок. Прикладом таких невдалих «нових», а по суті давно 
знаних образів стали портрети Михайла Дорошенка, які є реплікою відомого іконографічного типу, що репрезентує Петра Дорошенка (див. № 9).

Дещо більший інтерес становлять два твори, виконані в батальному жанрі: полотно Андрія Холоменюка "Герць козацького полковника Михайла Дорошенка 3 ногайським ханом Кантиміром Мурзою" з величезної авторської серії творів із назвою "Хотинська війна 1621 року” (див. № 10) і картина Андрія Серебрякова "Гетьман Петро Конашевич-Сагайдачний та полковник Михайло Дорошенко біля Арбатських воріт Москви жовтень 1618 рік” (див. № 11), яку виконав художник на замовлення Олексія Дорошенка у 2020 р. (попередній варіант картини автор створив ще у 2015 р. 3 численними очевидними історичними помилками). Попри те, що козацьке військо Михайла Дорошенка справді брало участь в Альмінській битві проти ногайської орди з Буджаку на чолі з Кантиміром (Кан-Теміром), не факт, що сам гетьман мав із ним особистий герць. Так само, як Петро Конашевич-Сагайдачний та Михайло Дорошенко, хоча й були під Москвою в 1618 р., проте не факт, що вони одночасно могли опинитися біля Арбатських воріт, оскільки рухалися на Москву різними шляхами. Загалом ці полотна мало цікаві 3 історичного погляду. Водночс вони можуть бути привабливими з погляду мистецького, виховного та популяризаторського, коли йдеться про поширення зацікавленості вітчизняною історією. Образ Михайла Дорошенка в обох творах $\epsilon$ фантастичним, створеним творчою уявою митців.

На тлі цілком зрозумілого процесу творення нових інтерпретацій образу відомого козацького ватажка та засновника козацько-старшинського роду незрозумілим залишається факт, чому в 2015 р. при створенні поштової віньєтки (поштового блоку) козацької та пластової пошти України в серії “Гетьмани України” для створення образу Михайла Дорошенка знову використали портрет Юрія Хмельницького у виконанні Джованні Баттісто Боначіни (див. № 16 та № 17).

Те саме питання виникає при дослідженні іконографічного складника пам'ятної медалі, випущеної Національним банком України 2008 р. до річниці смерті Михайла Дорошенка (див. № 21) та пам’ятного значка, виготовленого, імовірно, з тієї самої нагоди (див. № 22).

Поза увагою авторів цієї статті свідомо залишено багато зображень Михайла Дорошенка, частина з яких перебуває в приватній колекції Олексія Дорошенка, оскільки вони не мають ані історичної, ні мистецької цінності. Більшість з них репродукують у кращій чи гіршій якості автентичне зображення Юрія Хмельницького 1670 р. або інтерпретацію цього самого гравійованого зображення, виконану в 1991 р. Олександром Котом.

Що стосується скульптурних портретів Михайла Дорошенка, виконаних як погруддя чи поясні пам'ятники, то варто констатувати, що ні в Україні, ні за кордоном їх немає. Так само, як і пам'ятних знаків або меморіальних дощок, установлених на честь гетьмана. Однак це не означає, що не було спроб це зробити. Зокрема, одну з перших пропозицій щодо встановлення погруддя або пам'ятного знаку Михайлові Дорошенку висловив морський офіцер, дослідник історії українського флоту Мирослав Мамчак у книжці “Флотоводці, командувачі флоту України" (2005) [16, 17].

У 2008 р. до Бахчисарайської районної державної адміністрації та кримськотатарського Меджлісу звернулося Луганське відділення партії “Свобода” щодо встановлення пам'ятного знаку на честь Михайла Дорошенка [15]. У зверненні йшлося про створення ініціативної групи для створення ескізу, однак подальша доля цієї ініціативи очевидна, насамперед через події 2014 р., пов'язані з анексією Криму.

У 2009 р. Міністерство культури і туризму та Всесвітній конгрес українців підписали меморандум про співпрацю, в межах якого планували встановити пам'ятники жертвам Голодомору 1932-1933 pp. у Вашингтоні, Тарасу Шевченку в Астані (Казахстан), Михайлу Дорошенку в республіці Комі (Північно-Західний федеральний округ Російської Федерації) i Пилипу Орлику в Швеції [19]. 3 усіх цих задумів вдалося реалізувати лише один: 29 червня 2011 р. у шведському місті Крістіанстад відкрили пам'ятник і пам'ятну дошку українському гетьману Пилипу Орлику (автори - Олесь та Олена Сидоруки). Нинішні політичні обставини та відсутність нормальних відносин між Україною та Росією через війну роблять неможливим 
встановлення найближчим часом пам'ятника або пам'ятного знаку Михайлові Дорошенку на території РФ або в анексованому Криму.

Одночасно зі згаданою ініціативою Міністерства культури і туризму та Всесвітнього конгресу українців у 2009 р. $з$ ідеєю встановити пам'ятник Михайлу Дорошенку виступив Олекса Гайворонський - тодішній заступник директора Бахчисарайського державного історико-культурного заповідника з наукової роботи [5, с. 8]. Пам'ятник планували встановити на місці останнього бою гетьмана - біля річки Альми, неподалік Бахчисарая на території селища Новопавлівка (колишне селище Хан-Елі) [5, с. 27]. Того самого року цю ініціативу обговорювали на зборах Народного руху України. Планували оформити все як своєрідну “толоку” кримських українців, тобто оголосити збір коштів на виготовлення цього “народного пам'ятника". Намагаючись отримати підтримку тогочасної влади, Олекса Гайворонський зустрічався з головою Бахчисарайської РДА та Президентом України Віктором Ющенком. В обох випадках ідея мала щире схвалення, однак до її втілення справа не дійшла.

У червні 2018 р. під час презентації книги Андрія Іванця "Перший Курултай" Олексій Дорошенко, президент “Гетьманського фонду Петра Дорошенка", публічно отримав підтримку ідеї встановити пам'ятник Михайлу Дорошенку на півострові Крим від голови Меджлісу кримськотатарського народу Рефата Чубарова. На початку 2020 р. Олексій Дорошенко звернувся до Меджлісу щодо підписання Меморандуму про співпрацю, одним 3 пунктів якого було встановлення пам'ятника після деокупації Криму на спільно узгодженому місці. До того часу мав бути розроблений ескіз та створений макет пам'ятника. Відповідь на висловлену пропозицію не надійшла досі.

Отже, можна констатувати, що на 2021 р. кількість творів мистецтва 3 зображенням Михайла Дорошенка, є незначною. Серед них: 2 картини за батальними сюжетами, 4 малюнки на папері тушшю, олівцем та аквареллю, 5 живописних портретів, виконаних у різних техніках та в авторській манері митців, 3 графічні зображення на конвертах, 1 графічне зображення на поштовій картці, 2 зображення на поштових віньєтках козацької та пластової пошти України, 2 зображення на приватних наддруках на маркових блоках часів СРСР, 1 зображення на марці, 2 пам'ятних медалі та 1 пам'ятний значок, на яких було використано помилкові іконографічні типи. Крім описаних та проаналізованих у статті зображень Михайла Дорошенка, власник колекції також виявив чимало маловартісних ілюстрацій, які не залучено до опису та аналізу.

Відсутність автентичного прижиттєвого портрета Михайла Дорошенка, як і багатьох інших історичних постатей, життя яких припало на другу половину XVI - першу половину XVII століття, зумовили відсутність усталеної іконографії цього козацького ватажка. Усі наявні нині зображення було створено впродовж 1991-2021рp. Їхніми авторами є українські художники та графіки. Деякі з виявлених так званих портретів Михайла Дорошенка було створено на основі гравійованого портрета Юрія Хмельницького, виконаного італійським художником і гравером доби бароко Джованні Баттісто Боначіною у 1670 р. Інші зображення $\epsilon$ плодом творчої уяви митців і не наслідують жоден іконографічний тип. Окремі зображення відверто дублюють портрети Петра Дорошенка, створені впродовж різних періодів на основі двох прижиттєвих гравюр 1674 та 1693 рр., виконаних німецькими граверами, одним з яких був Йоганн Мартін Лєрх [12, с. 52; 13, с. 77-78; 14, с. 44, 52].

Оскільки могила Михайла Дорошенка не збереглася, а могила Петра Дорошенка розташована на території Російської Федерації, здійснення будь-яких ексгумацій, остеологічних досліджень та антропологічних реконструкцій зовнішності обох представників відомого козацько-старшинського роду українськими дослідниками поки що не $є$ можливим. Відтак, створені найближчим часом портретні зображення Михайла та Петра Дорошенків залишатимуться уявними.

\section{Джерела та література:}

1. Андрєєв В., Руденко А. Рід Дорошенків у громадсько-політичному та культурному житті України (XVII-XX ст.). Укр. іст. журн. 2015. № 1. С. 39-56. 
2. Брехуненко В., Грибовський В., Мицик Ю., Піскун В., Синяк І., Тарасенко I. Між конфронтацією та взаємодією: українсько-кримські та українсько-ногайські стосунки у XVII першій половині XX ст. / за ред. В. Брехуненка. Київ : ІУАД, 2018. 344 с.

3. Брехуненко В. А. Кримський ханат i проблема міжнародного визнання Ранньомодерної Української держави та суб'єктивації Війська Запорозького Низового. Проблеми історії країн Центральної та Східної Свропи : зб. наук. пр. Кам'янецьПодільський : Кам’янець-Поділ. нац. ун-т ім. Івана Огієнка, 2016. Вип. 5. С. 93-102.

4. Гайворонский О. Повелители двух материков. Т. 2 : Крымские ханы первой половины XVII столетия в борьбе за самостоятельность и единовластие. Киев ; Бахчисарай : Майстерня книги, Оранта, 2009. С. 117-124.

5. Гайворонський О. «Гетьман, що загинув за хана»: огляд подій кримського походу Михайла Дорошенка 1628 року. Гетьманська Украӥна між Польщею, Росією та Туреччиною. Ніжин, 2019. С. 7-39.

6. Грушевський М. Дорошенко Михайло (1913). Грушевський М. С. Твори : у 50 т. Львів : Світ, 2009. Т. 9. С. 252.

7. Домановский А. Н. Загадки истории. Крымское ханство. Харьков : Фолио, 2017. 384 с.

8. Дорошенко Д. Гетьман Петро Дорошенко: огляд його життя і політичної діяльності / за ред. В. Омельченка. Нью-Йорк : Видання Вільної Академії Наук у США, 1985. 712 с.

9. Дорошенко Д. Повстання Жмайла і козацькі походи в Крим. Укр. доброволеиь. 1944. № 60.

10. Журавльов Д. Усі гетьмани України. Харків : Фоліо, 2011. 508 с.

11. Замлинський В.О. Гетьмани України : монографія. Луганськ : ДЗ «ЛНУ ім. Тараса Шевченка», 2008. 287 с.: іл.

12. Ковалевська О. Зображення крізь віки: іконографія козацької старшини XVII-XVIII ст. Ч. 1. Київ : НАН України, Ін-т історії України, 2014. 314 с.

13. Ковалевська О. Зображення крізь віки: іконографія козацької старшини XVII-XVIII ст. Ч. 2. Київ: НАН України, Ін-т історії України, 2014. 330 с.: іл.

14. Ковалевська О. Таємниці козацьких портретів. Київ : Кліо, 2019. 288 с.: іл.

15. Луганская «Свобода» обращается к властям Бахчисарая с просьбой поставить памятник гетману Михаилу Дорошенко. URL: https://bit.ly/3HEufqm (дата звернення: 26.04.2021).

16. Мамчак М. Флотоводці України: історичні нариси, хронологія походів. Снятин : ПрутПринт, 2005. 400 с.

17. Мамчак M. Флотоводці, командувачі флоту України. URL: http://ukrlife.org/main/evshan/mamchak_flotovodci.html (дата звернення: 28.04.2021).

18. Мельник К. Сведения о походе в Крым Михаила Дорошенко. Киевская старина. 1896. №11 (нояб.). С. 274-286.

19. Минкультуры и Всемирный конгресс украинцев подписали меморандум о сотрудничестве. URL: https://bit.ly/3Fwjjcv (дата звернення: 28.04.2021).

20. Мицик Ю. Михайло Дорошенко. Україна в минулому. Київ ; Львів, 1994. Вип. 5. C. $156-170$.

21. Смолій В. Петро Дорошенко. Історія України в особах, IX-XVIII cm. / керівник авт. кол. В. Замлинський. Київ : Україна, 1993. С. 318-326.

22. Чухліб Т. Козаки і татари. Україно-кримські союзи 1500-1700-х років. Київ : Вид. дім «Києво-Могілян. акад.», 2017. 290 с.

23. Чухліб Т. Магнат, козак і гайдамака. Боротьба за владу Русі-України з короною польською (1569-1769 рр.). Київ : Вид. дім «Києво-Могілян. акад.», 2018. 256 с.

\section{References:}

1. Andrieiev, V. \& Rudenko, A. (2015) Rid Doroshenkiv u promads'ko-politychnomu ta kulturnomu zhytti Ukrainy (XVII-XX st.). Ukrainskyi istorychnyi zhurnal, no. 1, pp. 39-56. [in Ukrainian]. 
2. Brekhunenko, V., Grybovs'kyi, V., Mycyk, Yu., Piskun, V., Syniak, I. \& Tarasenko, I. (2018) Mizh konfrontatsiieiu ta vzayemodiieiu. Ukrains 'ko-kryms 'ki ta ukrains'ko-nogais 'ki stosunky u XVII - pershii polovyni XX st. Kyiv: IUAD. [in Ukrainian].

3. Brekhunenko, V.A. (2016) Kryms'kyi khanat i problema mizhnarodnoho vyznannia Rannomodernoi Ukrains'koi derzhavy ta sub'iektyvatsii Viis'ka Zaporoz'koho Nyzovoho. Problemy istorii krain Tsentralnoi ta Skhidnoi Yevropy. Kam'ianets-Podils'kyi: Kam'yanets-Podils'kyi natsionalnyi universytet imeni Ivana Ohiienka, vol. 5, pp. 93-102. [in Ukrainian].

4. Gayvoronskiy, O. (2009) Poveliteli dvukh materikov. T. 2 (Krymskie khany pervoy poloviny XVII stoletiya $\mathrm{v}$ borbe za samostoyatelnost i edinovlastie). Kiev ; Bakhchisaray : Maysternya knigi, Oranta, pp. 117-124. [in Russian].

5. Gayvoronskiy, O. (2019) «Get'man, shcho zahynuv za khana»: oglyad podii kryms'koho pokhodu Mykhaila Doroshenka 1628 roku. Get'mans'ka Ukraina mizh Pol'shcheiu, Rosiieiu ta Turechchynoiu. Nizhyn, pp. 7-39. [in Ukrainian].

6. Grushevs'kyi, M. (1913) Doroshenko Mykhailo. In: Grushevs 'kyi M.S. Tvory: u 50 t. L'viv: Vydavnytstvo «Svit», t. 9, p. 252. [in Ukrainian].

7. Domanovskiy, A.N. (2017) Zagadki istorii. Krymskoe khanstvo. Kharkov: Folio. [in Russian].

8. Doroshenko, D. (1985) Get'man Petro Doroshenko. Ogliad yoho zhyttia i politychnoi diial'nosti. NewYork: Vydannya Vilnoi Akademii Nauk u SShA. [in Ukrainian].

9. Doroshenko, D. (1944) Povstannia Zhmaila i kozatski pokhody v Krym. Ukrains'kyi dobrovolets, no. 60. [in Ukrainian].

10. Zhuravl'ov, D. (2011) Usi get'many Ukrainy. Kharkiv: Folio. [in Ukrainian].

11. Zamlyns'kyi, V.O. (2008) Get'many Ukrainy. Lugans'k: DZ «LNU imeni Tarasa Shevchenka». [in Ukrainian].

12. Kovalevs'ka, O. (2014) Zobrazhennia kriz' viky: ikonografiia kozatskoi starshyny XVII-XVIII st. Kyiv: NAN Ukrainy, Instytut istorii Ukrainy, ch. 1. [in Ukrainian].

13. Kovalevs'ka, O. (2014) Zobrazhennya kriz' viky: ikonografiya kozatskoi starshyny XVII-XVIII st. Kyiv: NAN Ukrainy, Instytut istorii Ukrainy, ch. 2. [in Ukrainian].

14. Kovalevs'ka, O. (2019) Tayemnytsi kozats'kykh portretiv. Kyiv: TOV «Vydavnytstvo "Klio"». [in Ukrainian].

15. Glavnyy sayt novostey v Luganske i Luganskoi oblasti (2008) Luganskaya «Svoboda» obrashchaetsya k vlastyam Bakhchisaraya s prosboy postavit pamyatnik getmanu Mikhailu Doroshenko. Available at: <https://cxid.info/54151_luganskaya-svoboda-obraschaetsya-k-vlastyam-baxchisaraya-sprosboi-postavit-pamyatnik-getmanu-mixailu-doroshenko.html> [Accessed 26 April 2021].

16. Mamchak, M. (2005) Flotovodtsy Ukrainy: istorychni narysy, khronologiia pokhodiv. Snyatyn: PrutPrynt. [In Ukrainian].

17. Mamchak, M. (2020) Flotovodtsi, komanduvachi flotu Ukrainy. 2nd ed. Available at: <http://ukrlife.org/main/evshan/mamchak_flotovodci.html> [Accessed 26 April 2021].

18. Mel'nyk, K. (1896) Svedeniya o pokhode v Krym Mikhaila Doroshenko. Kievskaya starina, no. 11 (Nov.), pp. 274-286. [In Russian].

19. Minkultury i Vsemirnyy kongress ukraintsev podpisali memorandum o sotrudnichestve. Available at: <https://www.rbc.ua/rus/news/minkultury_i_vsemirnyy_kongress_ukraintsev_ podpisali_memorandum_o_sotrudnichestve_1251365029> [Accessed 26 April 2021].

20. Mycyk, Yu. (1994) Mykhailo Doroshenko. Ukraina v mynulomu, issue 5. Kyiv; Lviv, pp. 156-170. [In Ukrainian].

21. Smolii, V. (1993) Petro Doroshenko. In: Istoriia Ukrainy v osobax, IX-XVIII st. Kyiv: Vydavnytstvo «Ukraina», pp. 318-326. [In Ukrainian].

22. Chukhlib, T. (2017) Kozaky i tatary. Ukraino-kryms'ki soiuzy 1500-1700-kh rokiv. Kyiv: Vydav. Dim «Kyievo-Mohilians'ka akademiia». [In Ukrainian].

23. Chukhlib, T. (2018) Magnat, kozak i haidamaka. Borot'ba za vladu Rusi-Ukrainy z koronoiu pol's'koiu (1569-1769 rr.). Kyiv: Vydav. Dim «Kyievo-Mohylians'ka akademiia». [In Ukrainian]. 


\section{ІЛЮСТРОВАНИЙ ДОДАТОК}
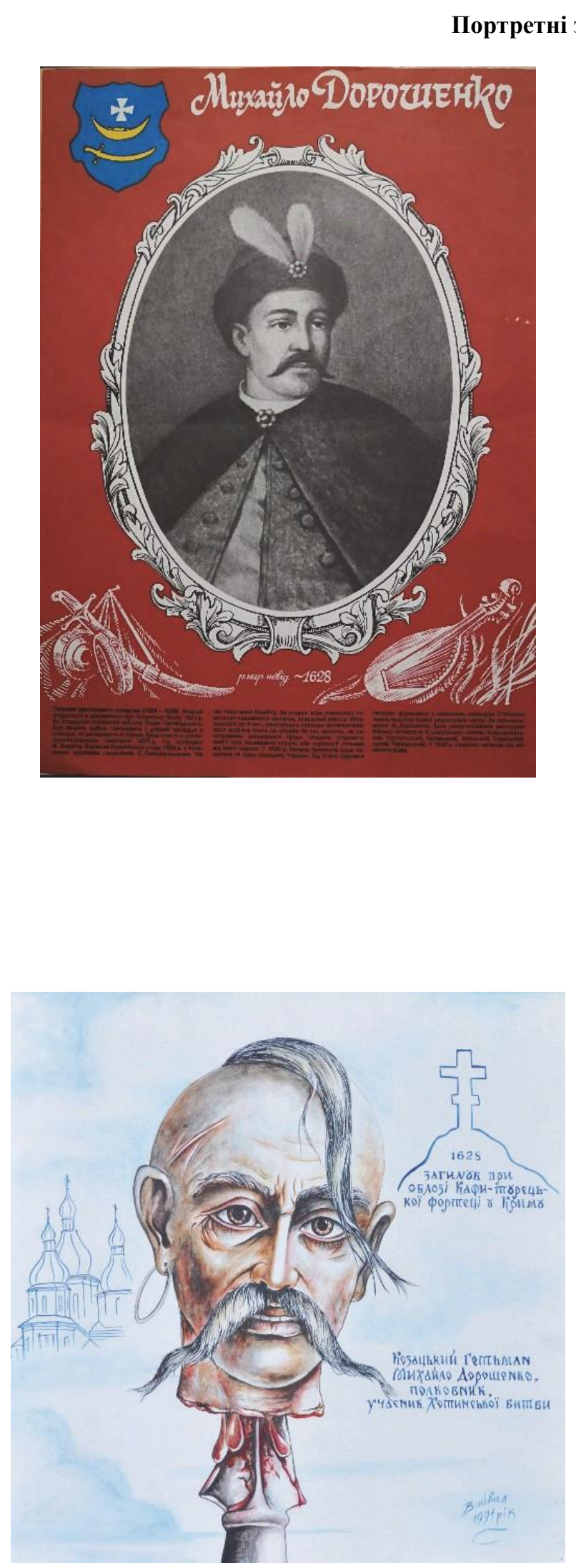

1. Олексій Кот.

Плакат «Михайло Дорошенко», 1991 р.

Папір, друк.

Розмір: 27,5 х 39,8 см.

Походження:

Приватне зібрання О. Дорошенка.

Примітка:

Публікується за примірником з колекції 16 плакатів «Гетьмани України». Авторами-упорядниками були Г.І. Ярова, І.В. Кардаш, Л.С. Верьовка. Підписано до друку 1.07.1991 р. Надруковано видавництвом «Україна».

Портретних рис М. Дорошенка не відображає. За основу зображення гетьмана взятий гравірований образ Ю. Хмельницького, створений Джованні Баттісто Боначіною 1670 p.

Інформачія про художника:

Кот Олександр Михайлович (р.н. 1960) художник, ілюстратор, журналіст. Закінчив НАОМА. Має 12 персональних виставок, 100 оформлених книжкових видань. Лауреат багатьох Всеукраїнських та міжнародних конкурсів плакату. Відзначений премією ЮНЕСКО за популяризацію культурної спадщини України. Член Національної спілки журналістів України з 1989 р. Працює викладачем рисунку та шрифтів у Коледжі КНУТД.

\section{2. Валерій Войтович.}

\section{«Козацький гетьман Михайло Дорошенко»,}

1991 p.

Папір, акварель.

Розмір: 21 х 29,7 см.

Походження:

Приватна колекція В. Войтовича.

Примітка:

Публікується за оригіналом. Фото В. Войтовича. Портретних рис М. Дорошенка не відображає. Є плодом творчої уяви автора.

Інформачія про художника:

Войтович Валерій Миколайович (р.н.1952) мистецтвознавець, письменник, мандрівник, дослідник української міфології. Член Національної спілки художників України; почесний член Національної спілки журналістів України; член Національної спілки краєзнавців України. Народився 8 травня 1952 року на хуторі Радочі поблизу села Вичівка, що на Рівненщині. 31989 року - на творчій роботі; у 1999-2012 роках старший викладач Національного університету «Острозька академія». Автор книг: «Українська міфологія», «Міфи та легенди давньої України», «Антологія українського міфу. У 3-х т.», «Генеалогія богів давньої України», «Українське міфологієзнавство», «Томаш Оскар Сосновський. Скульптура класицизму». Учасник багатьох регіональних та всеукраїнських художніх виставок. Автор пам'ятних знаків: художнику Нілу Хасевичу у с. Сухівці; загиблим у німецько-фашистському таборі у Клевані; останньому гетьману Запорозької Січі Петру Калнишевському, що на Рівненщині. 

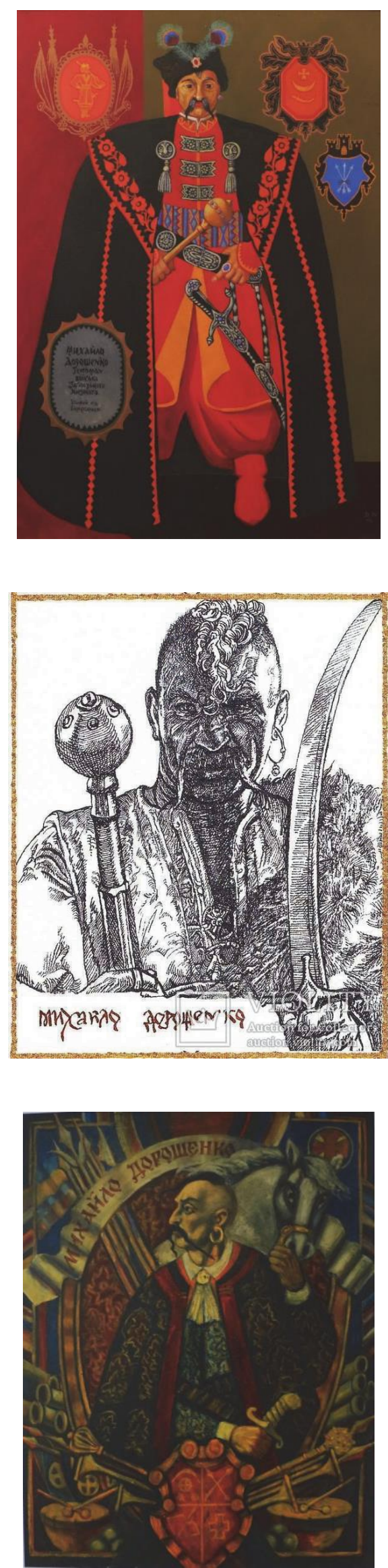

\section{3. Данило Нарбут.}

«Михайло Дорошенко. Гетьман України (1622-1628)», 1991 p.

Полотно, темпера.

Розміри: невизначено.

Походження:

Національний історико-культурний заповідник «Чигирин».

Примітка:

Портретних рис М. Дорошенка не відображає. Є плодом творчої уяви автора. Фото О. Ковалевської.

Інформачія про художника:

Нарбут Данило Георгійович (1916-1998) - український художник театру, живописець. Син художника-графіка Георгія Нарбута. Народний художник України (1994), лауреат Шевченківської премії (1996). За портретні серії «Сподвижники Б. Хмельницького», «Гетьмани України», а також за філософсько-історичне полотно «Страшний суд», чуттєві й високохудожні картини «Вибори кошового» та «Покрова Богородиці» отримав Державну Шевченківську премію.

\section{4. Сергій Якутович.}

«Михайло Дорошенко», 1994 р.

Папір, туш, перо.

Розміри: невизначено.

Походження:

Власність родини Якутовичів.

Примітка:

Портретних рис М. Дорошенка не відображає.

Інформачія про художника:

Якутович Сергій Георгійович (1952-2017) - український художник, графік, книжковий ілюстратор, народний художник України, лауреат Національної премії України ім. Тараса Шевченка, член Національної спілки художників України, член-кореспондент Академії мистецтв України. Створив серію портретів гетьманів та козацьких ватажків для календаря на 1994 рік.

\section{5. Феодосій Гуменюк.}

«Гетьман Михайло Дорошенко», 2006 р.

Полотно, олія

Розмір: 150 х $115 \mathrm{~cm}$.

Походження:

Власність художника.

Примітка:

Публікується за виданням: Україна від Трипілля до сьогодення в образах сучасних художників: Каталог третьої Всеукраїнської виставки / Упоряд. О. Мельник. - К., 2008. С. 68. Портретних рис М. Дорошенка не відображає. Є плодом творчої уяви автора.

Інформачія про художника:

Гуменюк Феодосій Максимович (р.н. 1941) - український живописець, графік, лауреат Шевченківської премії (1993), народний художник України (з 2009), Заслужений діяч мистецтв України, член Національної Спілки художників України. 


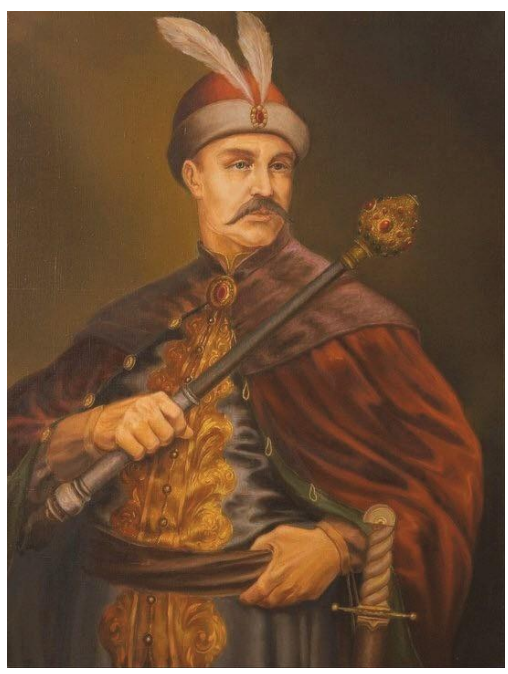

\section{6. Семен Панпушин.}

«Гетьман Михайло Дорошенко», 2007 р.

Полотно, олія.

Розмір 70 × $92 \mathrm{~cm}$.

Походження:

Приватна колекція Ю. Дорошенка.

Примітка:

Публікується за примірником 3 колекції. В основі зображення помилковий портрет Михайла Дорошенка, запозичений художником з книги В. Антоновича «Про козацькі часи на Україні». Насправді художник не знав, що послуговувався гравірованим портретом гетьмана Ю. Хмельницького, створеним Джованні Баттісто Боначіною 1670 р. За задумом художника тлом картини мало стати зображення Хотинської фортеці. Однак проблеми зі здоров'ям завадили художнику закінчити цей твір.

Інформація про художника:

Панпушин Семен Вікторович (1956-2014) - український художник, іконописець. Мешкав у Херсоні. Мав педагогічну та художню освіту. Писав ікони, розписував іконостаси, церкви, створював портрети історичних та сучасних діячів. Автор серії портретів Київських митрополитів, яка перебуває в стінах Київської Духовної академії (загалом 107 портретів). Крім того створив кілька портретів київських князів та гетьманів. Брав участь у розписі та оздобленні Катериненського, Святодухівського, Святоолександрівського храмів у Херсоні. Здійснив підготовчі роботи для розпису церви Всіх Святих, однак не завершив через передчасну смерть.

\section{7. Олексій Томін.}

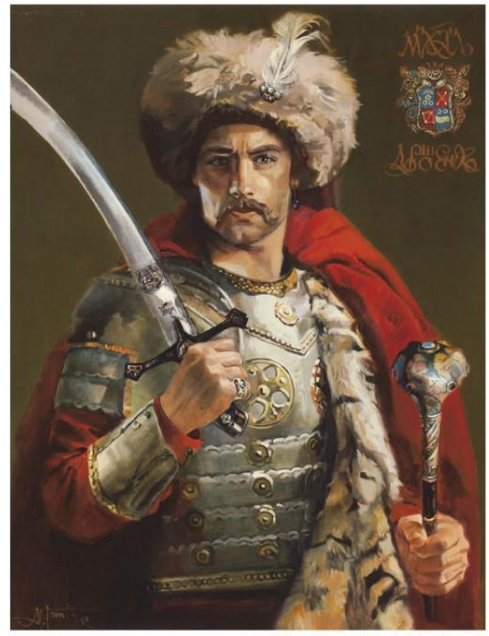

«Михайло Дорошенко», 2013 р.

3 серії «Гетьмани України».

Полотно, олія.

Pозмір: 70 × $90 \mathrm{~cm}$.

Походження:

Галерея «N-Prospect» (м. Санкт-Петербург).

Примітка:

Публікується за матеріалами сайту галерії. Режим доступу:

https://n-prospect.ru/1120005.html.

Портретних рис М. Дорошенка не відображає. $Є$ плодом творчої уяви автора. Картина не брала участі у виставках, не включена до альбомів чи каталогів.

Інформація про художника:

Томін Олексій Георгійович (1961-2016) - український художник, майстер міського архітектурного пейзажу, історичного філософсько-духовного фігуративного живопису. Працював у техніці акварелі, олійного живопису та оригінальній техніці, використовуючи фактуру деревини. Особливе місце в творчості займав монументальний розпис. Перша персональна виставка відбулася 1989 р. Створив понад 1000 робіт, які знаходяться в приватних колекціях понад тридцяти країн світу, а також у колекції митрополита Володимира (Сабодана). Окремі полотна прикрашають приміщення Адміністрації Президента України.

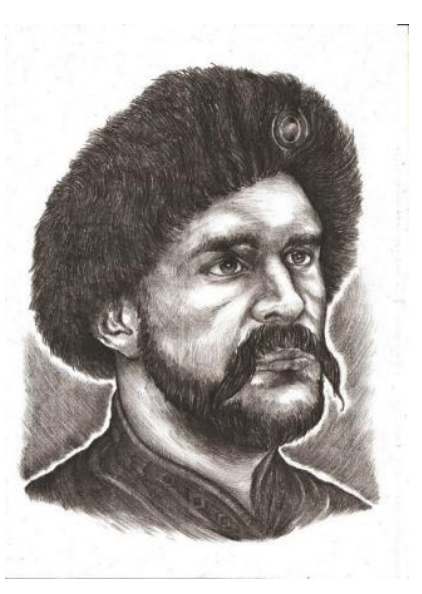

8. Cossack.

«Молодий Михайло Дорошенко», 2015 р.

Папір, олівець.

Pозмір: 21 х 29,7 cм.

Походження:

Приватне зібрання О. Дорошенка.

Примітка:

Публікується за примірником з колекції. Портретних рис М. Дорошенка не відображає. Є плодом творчої уяви автора.

Інформачія про художника:

Cossack (?) - молодий український художник, графік. Саме під цим псевдонімом, бо власним ім'ям він ніколи не підписується. «Козак» створив низку портретів видатних постатей української історії. Створюючи мистецькі реконструкції образів козацьких ватажків, оформив низку поштових конвертів та листівок. 


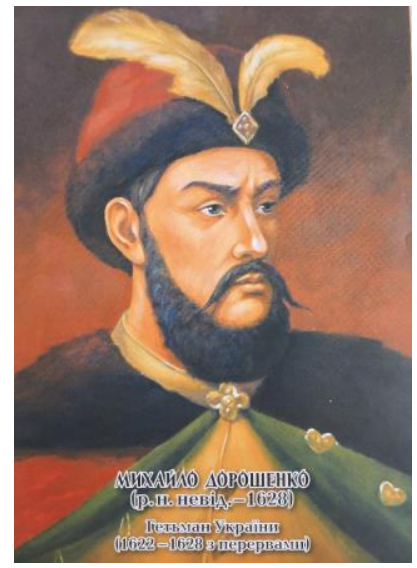

9. Художник невизначений.

«Гетьман Михайло Дорошенко»

Аркуш з календаря «Гетьмани України» за 2016 р.

Колір: повнокольоровий.

Розмір: 4 х 2,7 см.

Походження:

Приватне зібрання О. Дорошенка.

Примітка:

Публікується за примірником з колекції. Видавець та вихідні дані календаря не вказані. У виданні після гетьмана П. Конашевича-

Сагайдачного було представлено М. Дорошенка. Однак за основу образу було взято іконографічний тип зображень Петра Дорошенка, який походив від відомої гравюри Йоганна Мартіна Лєрха. Для репрезентації образу самого Петра Дорошенка, ілюстратор використав інше відоме зображення онука Михайла Дорошенка.

\section{Картини за історично-баталістичними сюжетами}

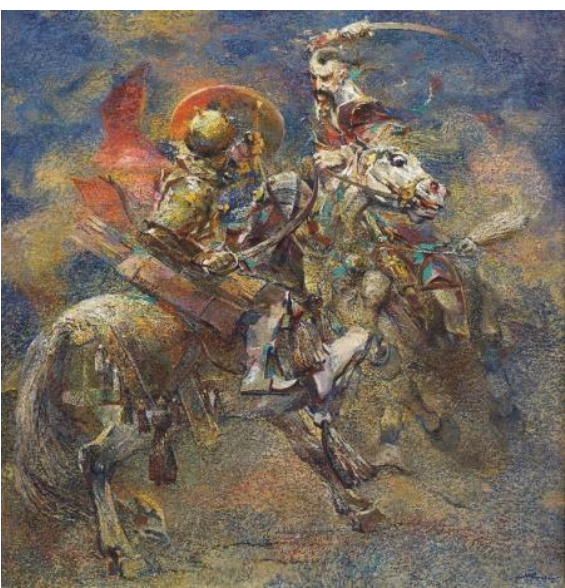

\section{0. Андрій Холоменюк.}

«Герць козацького полковника Михайла Дорошенка з ногайським ханом Кантеміром Мурзою», 2007 р.

Полотно, олія.

Розмір: 150 × $150 \mathrm{~cm}$.

Походження:

Галерея «Екогінтокс» Інституту екогігієни і токсикології Л.І. Медведя (Київ, вул. Героїв Оборони, 6).

Примітка:

Портретних рис М. Дорошенка не відображає. $Є$ плодом творчої уяви автора.

Інформачія про художника:

Холоменюк Андрій Іванович (р.н.1957) - український художник батального живопису. Закінчив Львівську національну академію мистецтв. Створив серію з 80 творів під назвою «Хотинська війна 1621 року». Одним із них була робота «Герць козацького полковника Михайла Дорошенка 3 ногайським ханом Кантеміром Мурзою». Член Національної спілки художників України, голова Правління «Студії військово-історичного мистецтва України». Має 35 персональних виставок. У його доробку понад 1,5 тисячі написаних картин.

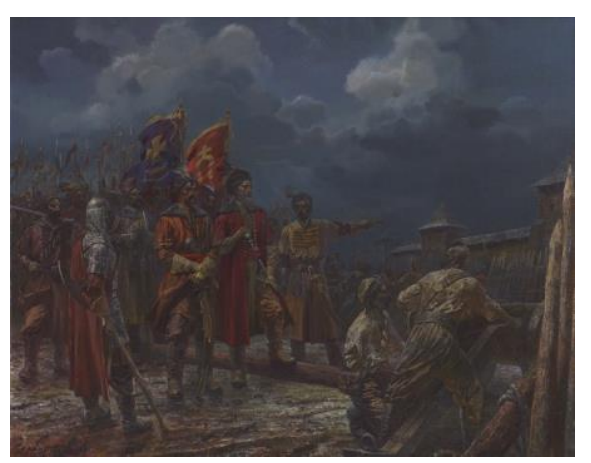

11. Андрій Серебряков.

«Гетьман Петро Конашевич-Сагайдачний та полковник Михайло Дорошенко біля Арбатських воріт Москви жовтень 1618 рік», 2020 p.

Полотно, олія.

Розмір: 110 х $70 \mathrm{~cm}$.

Походження:

Приватна колекція А. Серебрякова.

Примітка:

Публікується за оригіналом. Портретних рис М. Дорошенка не відображає. Є плодом творчої уяви автора.

Інформачія про художника:

Серебряков Андрій Вікторович (р.н.1966) - український художник, член Національної спілки художників України. Працює в стилі батального та історичного живопису. Народився 4 червня 1966 р. у м. Кіровськ на Луганщині. У 1982 р. вступив до художнього училища ВДХУ, курс М.О. Піщанського. З 1988 по 1995 рік навчався у Київському художньому інституті на факультеті живопису, майстерня Народного художника Української РСР, професора В.В. Шаталіна. Протягом 1996-2000 pp. на запрошення мистецьких галерей та приватних замовників працював у Туреччині, Саудівській Аравії й Австрії. Нині живе та працює в Києві. Багато років співпрацює 3 Національним військово-історичним музеєм України, Музеєм Гетьманства, мистецькими галереями та книжковими видавництвами країни. Значну частина творчого доробку складають твори на козацьку тематику. Більшість картин знаходяться у приватних зібраннях України, Австрії, Іспанії, Молдови, Португалії, Румунії, Туреччини, Саудівської Аравії, США та Китаю, також в музеях України та галереях Києва. 


\section{Філателія (малі графічні форми) з образом Михайла Дорошенка}
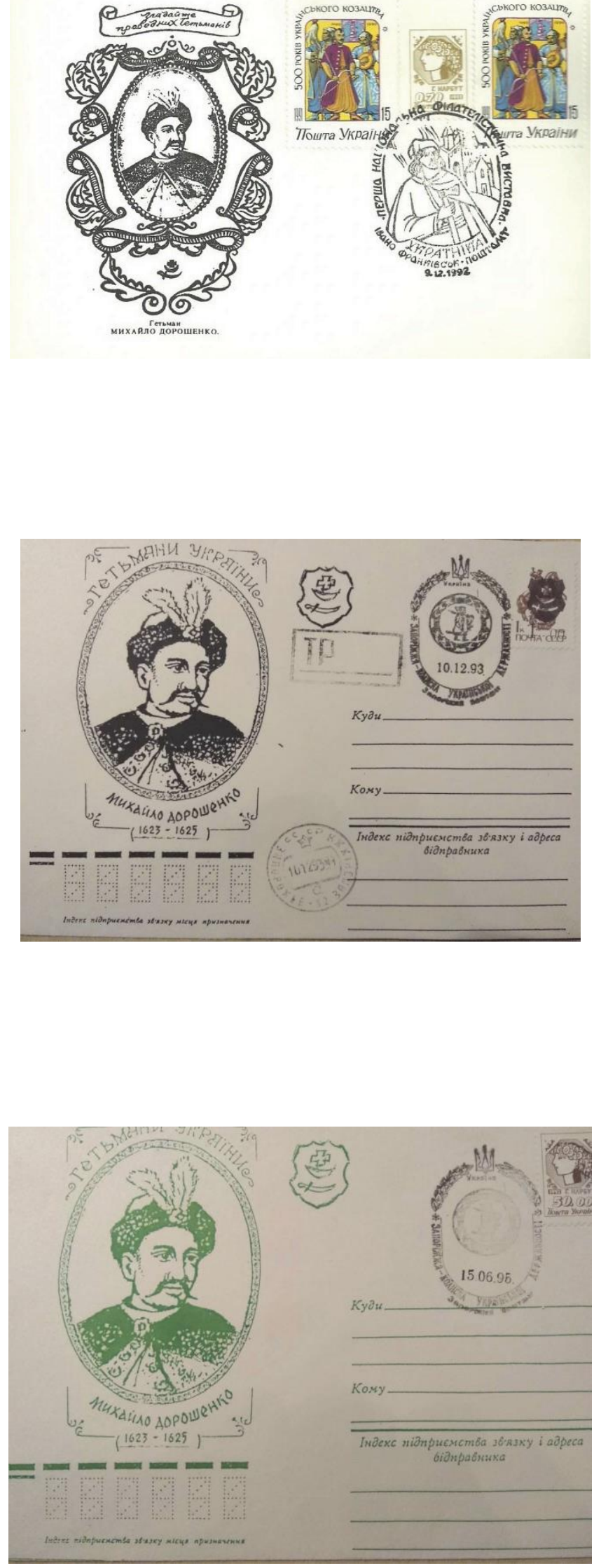

\section{2. Поштовий конверт з серії «Пригадайте} праведних гетьманів».

«Гетьман Михайло Дорошенко».

Погашення:

«Перша національна філателістична виставка».

Дата погашення: 9.12.1992.

Папір, друк.

Колір: чорний.

Розмір: 16 x 11,5 cм

Походження:

www.skylots.org.

Примітка:

Публікується за даними лота на www.skylots.org. Усього в серії 16 конвертів із зображеннями гетьманів. Портретних рис M. Дорошенка не відображає. За основу зображення гетьмана взятий гравірований образ Ю. Хмельницького, створений Джованні Баттісто Боначіною 1670 p.

\section{3. Поштовий конверт:}

«Гетьмани України. Михайло Дорошенко $(1623$ - 1625)».

Погашення:

«Запоріжжя - колиска української

державності».

Дата погашення: 10.12.1993.

Папір, друк.

Колір: чорний.

Розмір: 16,2 x 11,5 cм.

Художник-оформлювач: М. В. Ціон.

Тираж: 300 прим.

Походження:

Приватне зібрання О. Дорошенка.

Примітка:

Публікується за примірником з колекції.

Портретних рис М. Дорошенка не відображає.

За основу зображення гетьмана взятий

гравірований образ Ю. Хмельницького,

створений Джованні Баттісто Боначіною 1670 р.

\section{4. Поштовий конверт:}

«Гетьмани України. Михайло Дорошенко

(1623 - 1625)». Погашення:

«Запоріжжя - колиска української

державності».

Дата погашення: 15.06.1995.

Папір, друк.

Колір: зелений.

Розмір: 16 x 11,5 cм.

Художник-оформлювач: М. В. Ціон.

Тираж: 300 прим.

Походження:

Приватне зібрання О. Дорошенка.

Примітка:

Публікується за примірником з колекції.

Портретних рис М. Дорошенка не відображає.

За основу зображення гетьмана взятий

гравірований образ Ю. Хмельницького,

створений Джованні Баттісто Боначіною 1670 р. 

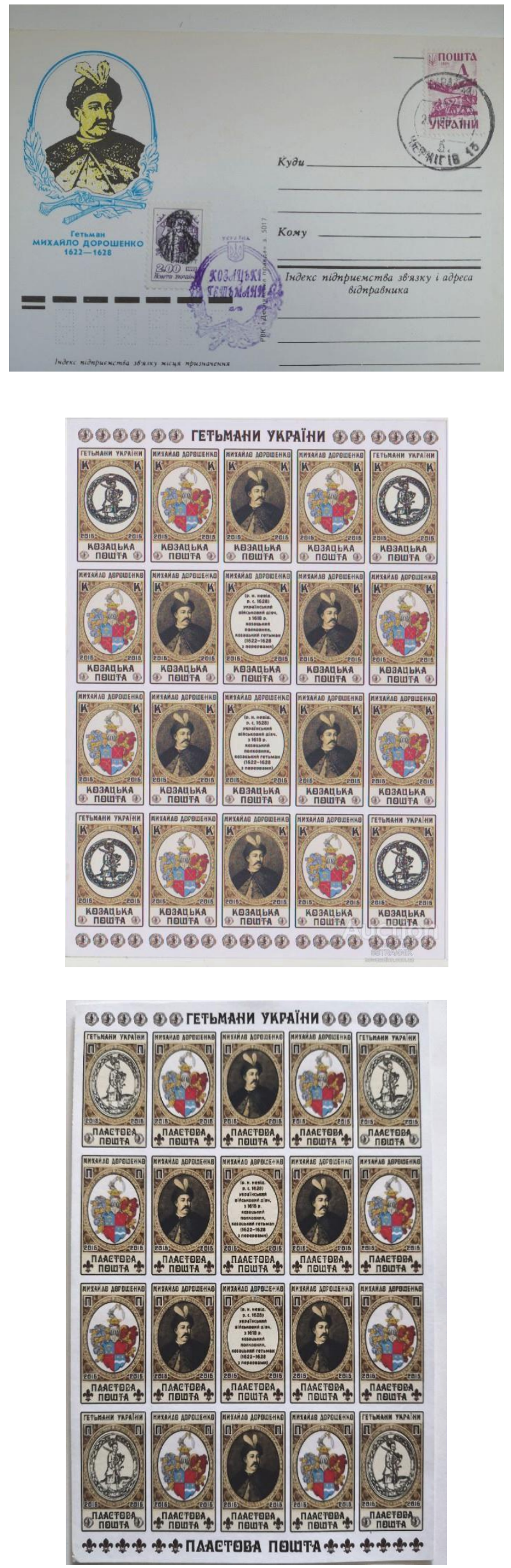

\section{5. Поштова картка.}

«Гетьман Михайло Дорошенко. 1622 - 1628».

РВК Деснянська правда.

Погашення: «Козацькі гетьмани» (Чернігів).

Дата погашення: 23.10.1995.

Папір, друк.

Колір: чорний, жовтий, блакитний.

Розмір: 15 x 10,5 см.

Походження:

Приватне зібрання О. Дорошенка.

Примітка:

Публікується за примірником 3 колекції. Портретних рис М. Дорошенка не відображає. За основу зображення гетьмана взятий гравірований образ Ю. Хмельницького, створений Джованні Баттісто Боначіною 1670 р.

\section{6. Поштова віньєтка. (Поштовий блок?) «Гетьмани України».}

«Михайло Дорошенко. 2015». Козацька пошта.

Папір, друк.

Колір: коричневий, жовтий, червоний,

блакитний.

Розмір: 15 x $21 \mathrm{~cm}$.

Походження:

Приватне зібрання О. Дорошенка.

Примітка:

Публікується за примірником з колекції.

Портретних рис М. Дорошенка не відображає.

За основу зображення гетьмана взятий

гравірований образ Ю. Хмельницького,

створений Джованні Баттісто Боначіною 1670 р.

\section{7. Поштова віньєтка. (Поштовий блок?) \\ «Гетьмани України».}

«Михайло Дорошенко. 2015». Пластова пошта.

Папір, друк.

Колір: коричневий, жовтий, червоний, блакитний.

Розмір: 15 × $21 \mathrm{~cm}$.

Походження:

Приватне зібрання О. Дорошенка.

Примітка:

Публікується за примірником 3 колекції. Портретних рис М. Дорошенка не відображає. За основу зображення гетьмана взятий гравірований образ Ю. Хмельницького, створений Джованні Баттісто Боначіною 1670 p. 

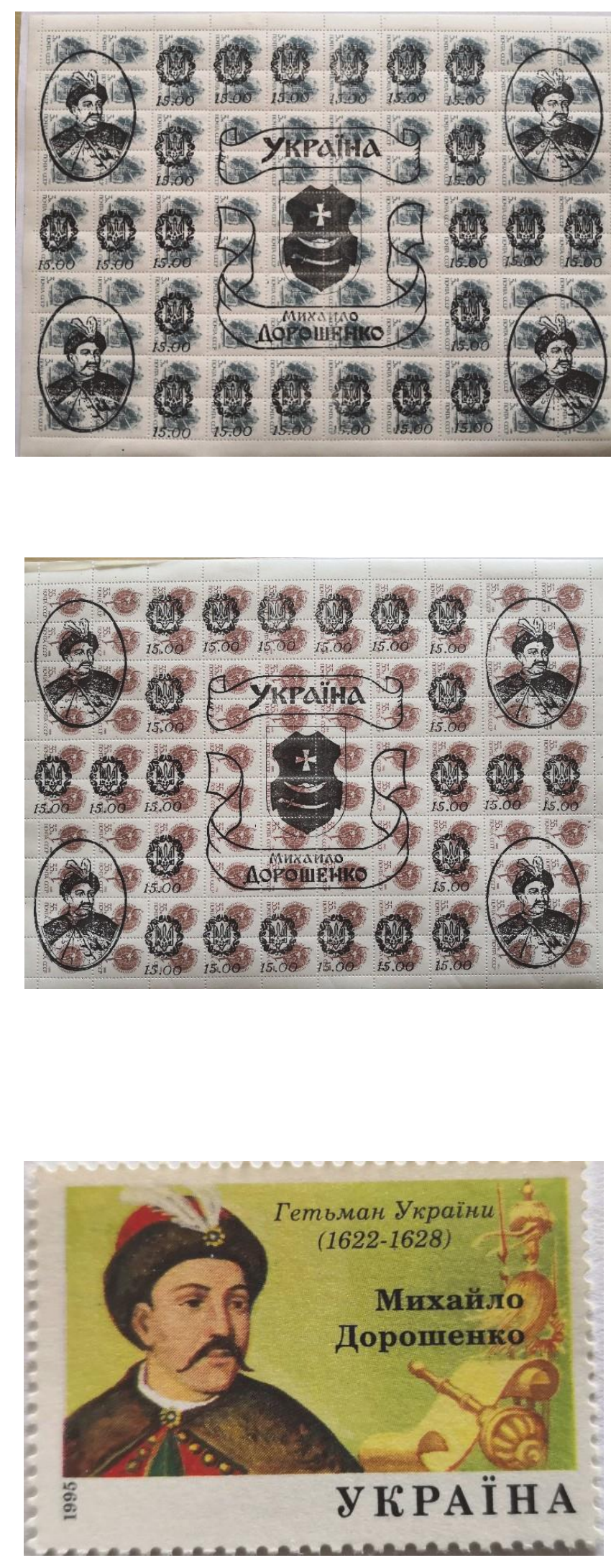

18. Приватний наддрук.

«Україна. Михайло Дорошенко» на аркуші поштових марок часів СРСР (рік невизначений).

(Поштова марка 1988 р. «Стандарт. Крейсер «Аврора». Номінал 3 коп. Художник марки

В. Коваль. Колір зелено-синій.)

Папір, друк.

Формат аркуша: 20,6 х 27,7 cм.

Формат кожної марки: 2,6 x 1,8 cм.

Походження:

Приватна колекція О. Дорошенка.

Примітка:

Публікується за примірником з колекції.

Портретних рис М. Дорошенка не відображає. За основу зображення гетьмана взятий гравірований образ Ю. Хмельницького, створений Джованні Баттісто Боначіною 1670 p.

\section{9. Приватний наддрук.}

«Україна. Михайло Дорошенко» на аркуші поштових марок часів СРСР (рік невизначений).

(Поштова марка 1988 р. «Міжнародне торгове співробітництво». Номінал 35 коп. Художник марки В. Коваль. На марці зображено скульптуру бога торгівлі Меркурія).

Колір: червоно-коричневий.

Папір, друк.

Формат аркуша: 20,8 × 27,3 cм.

Формат кожної марки: 2,6 х 1,8 cм.

Походження:

Приватна колекція О. Дорошенка.

Примітка:

Публікується за примірником 3 колекції. Портретних рис М. Дорошенка не відображає. За основу зображення гетьмана взятий гравірований образ Ю. Хмельницького, створений Джованні Баттісто Боначіною 1670 p.

\section{0. Марка.}

«Гетьман України (1622-1628) Михайло Дорошенко», 1995.

Папір, друк.

Колір: зелений, жовтий, коричневий, червоний, чорний.

Pозмір: 4 × 2,7 cм.

Походження:

Приватне зібрання О. Дорошенка.

Примітка:

Публікується за примірником з колекції.

Портретних рис М. Дорошенка не відображає. За основу авторської інтерпретації зображення гетьмана взятий гравірований образ

Ю. Хмельницького, створений Джованні Баттісто Боначіною 1670 p.

Пробні марки «Гетьмани України» становили серію з 16 шт. без номіналу. Друкувалися в Києві на ДП «Укрпошта» на замовлення

Кіровоградського поштампу. В обіг не надходили. Більшість тиражу була знищена. 


\section{Фалеристичні твори з образом з Михайла Дорошенка}

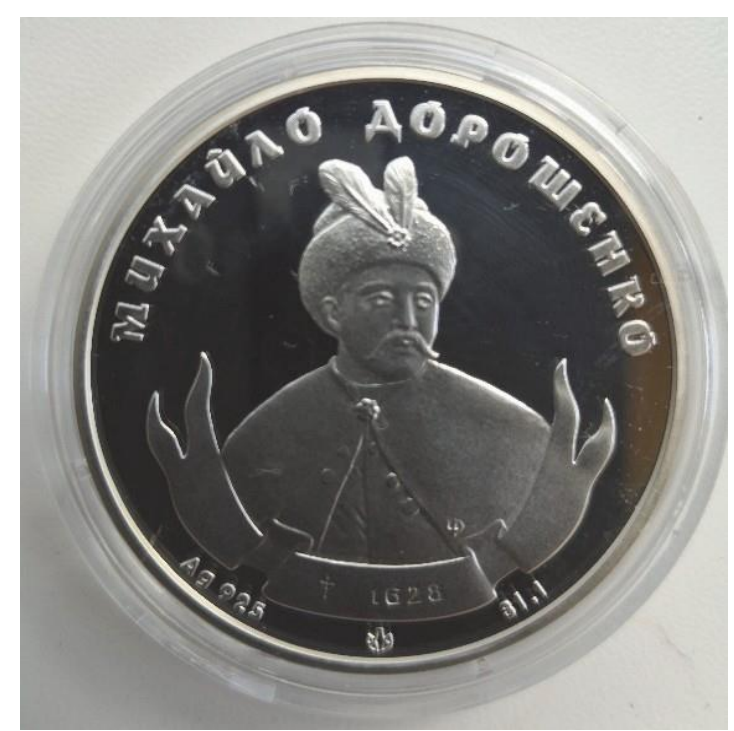

\section{1. Пам'ятна медаль.}

«Михайло Дорошенко», 2008 р.

Вага: 31,1 г.

Діаметр: 38,61 мм.

Метал: Ag 925.

Походження:

Приватна колекція О. Дорошенка.

\section{Примітка:}

Публікується за примірником з колекції. Портретних рис М. Дорошенка не відображає. $€$ плодом творчої уяви автора.

Усі медалі мають сертифікат, де вказаний іiі порядковий номер. Вони викарбувані на Монетному дворі Національного банку України наприкінці 2007 p. Репрезентовані були на початку 2008 р. За інформацією автора проекту - Дмитра Піркла всього було викарбовано 100 медалей зі срібла, 10 з яких, із позолотою. 3 срібних медалей 15 було патинованих. Після чого інструмент було знищено, про що $є$ відповідні документи.

Скульптор:

Роман Чайковський.

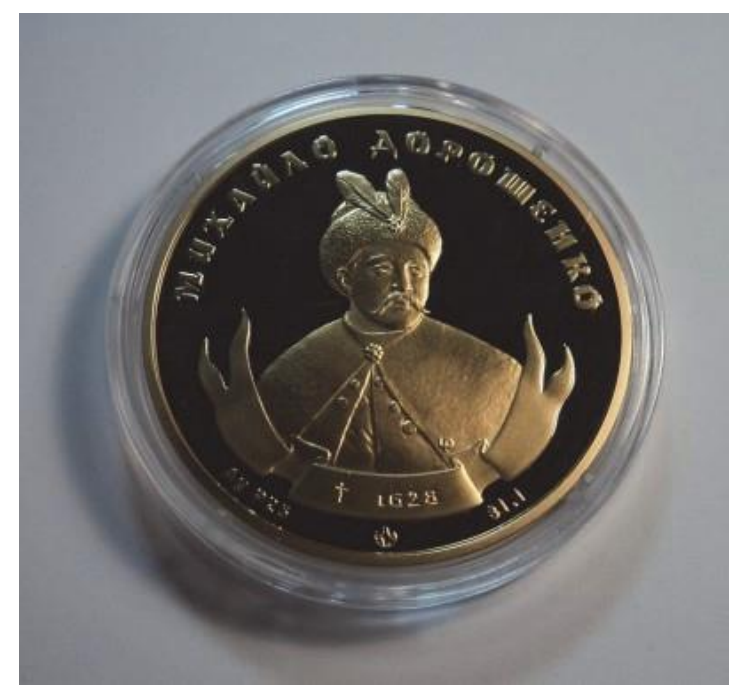

\section{2. Пам'ятна медаль.}

«Михайло Дорошенко», 2008 р.

Вага: 31,1 г.

Діаметр: 38,61 мм.

Метал: Ag 925 позолочена.

Тираж: 10 шт.

Походження:

\section{www.newauction.com.ua}

\section{Примітка:}

Публікується за матеріалами сайту www.newauction.com.ua

Портретних рис М. Дорошенка не відображає. Є плодом творчої уяви автора. Усі медалі мають сертифікат, де вказаний іï порядковий номер. Вони викарбувані на Монетному дворі Національного банку України наприкінці 2007 p. Репрезентовані були на початку 2008 р. За інформацією автора проекту - Дмитра Піркла всього було викарбовано 100 медалей зі срібла, 10 з яких, із позолотою. 3 срібних медалей 15 було патинованих.

Після чого інструмент було знищено, про що є відповідні документи.

Скульптор:

Роман Чайковський.

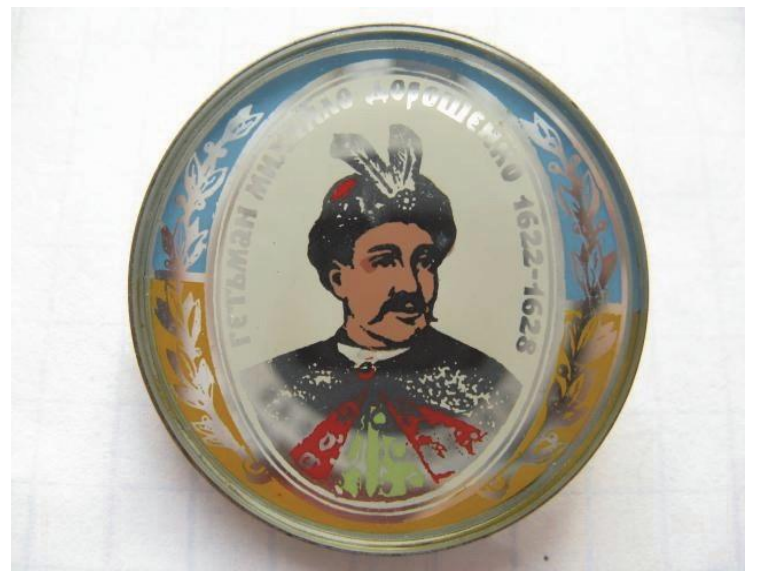

23. Пам'ятний значок.

«Михайло Дорошенко 1622 - 1628».

Рік виготовлення невизначено.

Метал, скло.

Діаметр: 8 см.

Походження:

Приватне зібрання О. Дорошенка.

Примітка:

Публікується за примірником з колекції. Портретних рис М. Дорошенка не відображає. $Є$ плодом творчої уяви автора. Придбаний О.Дорошенком в 2015 році. 